\title{
HUBUNGAN PENGETAHUAN DAN LAMA PEMAKAIAN KB SUNTIK 3 BULAN DENGAN PERUBAHAN BERAT BADAN PADA AKSEPTOR KB DI BIDAN PRAKTIK SWASTA VERONICA NONGSA BATU BESAR KOTA BATAM
}

\section{Relationship Of Knowledge And Long Use KB Inject Of 3 Months With Changes Weight Body For KB Acceptors In Bps Veronica Nongsa Batu Besar Of Batam City}

\author{
Indah Mastikana ${ }^{\text {* }}$ \\ *1,2 Program Studi Kebidanan, \\ STIKes Awal Bros Batam \\ Kepulauan Riau, Indonesia
}

*email: indahmst2@gmail.com

\begin{abstract}
Abstrak
KB Suntik 3 Bulan adalah kontrasepsi yang diberikan setiap 3 bulan sekali yang memiliki kandungan Hormon Progesterone. KB Suntik 3 bulan memiliki efek samping yaitu salah satunya adalah perubahan berat badan. Tujuan penelitian ini untuk mengetahui apakah ada hubungan pengetahuan dan lama pemakaian KB suntik 3 bulan dengan perubahan berat badan.

Desain penelitian yaitu Deskriptif Analitik dengan pendekatan Cross Sectional. Teknik sampel yang diambil dengan menggunakan teknik Total Sampling dengan jumlah sampel 60 orang.

Hasil penelitian ini yaitu mayoritas responden memiliki pengetahuan yang baik tentang KB suntik 3 bulan dengan perubahan berat badan meningkat, dari hasil uji Chi Square nilai $p$ value 0.585 . Dari hasil penelitian sebagian besar akseptor yang lama pemakaian KB suntik $>$ I tahun dengan berat badan meningkat dari hasil uji Chi Square nilai $p$ value 0,054 .
\end{abstract}

Kesimpulan penelitian tidak ada hubungan pengetahuan dan lama pemakaian KB suntik 3 bulan dengan perubahan berat badan pada akseptor KB.
Kata Kunci:

Pengetahuan

Lama Pemakaian

Perubahan Berat Badan

KB Suntik 3 Bulan

\section{Keywords:}

Knowledge

Long Use Injections

Changes Weight Bodys

$K B$ of inject 3 months

\begin{abstract}
$\mathrm{KB}$ injectable 3 months is contraceptives given every 3 months which contains of hormone progesterone. $K B$ injectable 3 months have effects that one of them is the change in weight. The purpose of this study to determine there is a relationship of knowledge and duration of use injections of 3 months with weight change.
\end{abstract}

Research design is Descriptive Analytic with cross sectional approach. Samples taken using Total Sampling with a sample size of 60 people.

The results of study most of the respondents had a good knowledge about KB of injectable 3 months with changes weight body, from result $p$ value of Chi Square 0,585. From results of study were mostly acceptor long use injectables $>$ I year with the increase weight, the results of Chi Square $p$ value 0,054.

The conclusion of the result is there is no relationship between knowledges and long use injections of 3 months with weight change of acceptors.

(c) year The Authors. Published by Institute for Research and Community Services Universitas Muhammadiyah Palangkaraya. This is Open Access article under the CC-BY-SA License (http://creativecommons.org/licenses/by-sa/4.0/). DOI: https://doi.org//0.33084/jsm.vxix.xxx.

\section{PENDAHULUAN}

Dinamika kependudukan merupakan perubahan kependudukan untuk suatu daerah tertentu dari waktu kewaktu. Masalah kependudukan yang terjadi di Indonesia adalah jumlah dan pertumbuhan penduduk, persebaran dan kepadatan penduduk, struktur umur penduduk, serta kualitas penduduk (Handayani, 20I0).
Indonesia merupakan Negara keempat terbesar penduduknya di dunia dengan lebih dari 237 juta jiwa. Fertilitas atau kelahiran adalah salah satu faktor penambah bagi jumlah penduduk. Untuk mengatasi hal tersebut, pemerintah Indonesia menerapkan program Keluarga Berencana (KB) yang telah dimulai sejak tahun 1968 dengan didirikannya LKBN (Lembaga Keluarga 
Berencana Nasional) yang kemudian pada tahun 1970 diubah menjadi BKKBN (Badan Koordinasi Keluarga Berencana Nasional) dengan tujuan dapat mewujudkan keluarga kecil yang bahagia dan sejahtera.

Untuk mengendalikan laju pertumbuhan penduduk maka perlu dilakukannya tindakan pengendalian jumlah penduduk yaitu dengan cara program Keluarga Berencana (KB), seperti slogan Keluarga Berencana (KB) yaitu dua anak lebih baik. Sehingga diharapkan jumlah penduduk dapat terkendali (Handayani, 20I0).

Keluarga Berencana merupakan tindakan yang membantu individu atau pasangan suami istri untuk mendapatkan objektif-objektif tertentu, menghindari kelahiran yang tidak diinginkan, mendapatkan kelahiran yang memang diinginkan, mengatur interval diantara kehamilan, mengontrol waktu saat kelahiran dalam hubungan dengan suami istri, dan menentukan jumlah anak dalam keluarga (Hartanto, 20I0).

Penggunaan setiap metode kontrasepsi mempunyai kelebihan dan kekurangan. Namun demikian, meskipun telah mempertimbangkan untung dan rugi dalam setiap kontrasepsi yang tersedia, tetap saja terdapat kesulitan untuk mengontrol fertilitas secara aman, efektif, dengan metode yang dapat diterima baik perorangan maupun budaya (Saiffudin, 2006).

Penambahan berat badan merupakan salah satu efek samping yang sering dikeluhkan oleh akseptor KB Suntik 3 bulan (Depo Medroksi Progesterone). Efek samping suatu metode kontrasepsi merupakan suatu faktor yang perlu dipertimbangkan dalam menentukan keputusan terhadap kelangsungan pemakaian metode kontrasepsi. Maka perlu diupayakan perlindungan dan efek samping sekaligus kelestariannya (Hartanto, 2010).

Efek penambahan berat badan pada suntik Depo Medkroksi Progesterone Asetate disebabkan karena Depo Medroksi Progesterone Asetate merangsang pusat pengendali nafsu makan di hipotalamus yang menyebabkan akseptor makan lebih banyak dari biasanya. Oleh karena itu, pada pemakaian kontrasepsi ini sering dikeluhkan adanya penambahan berat badan (Hartanto, 20I0).

Resiko peningkatan berat badan ini secara statistik tidak ada perbedaan pada bulan 12 bulan pertama penggunaan. Semakin lama penggunaan kontrasepsi hormonal maka resiko terjadinya obesitas akan semakin besar (Nurjanah, 2006).

Menurut BKKBN (Badan Kependudukan dan Keluarga Berencana Nasional) di provinsi Kepulauan Riau pada bulan Desember tahun 2015 mencatat jumlah peserta KB aktif yaitu 283.702 jenis kontrasepsi yang digunakan yaitu IUD 19.996 peserta, MOW 6.817 peserta, Implant 19.014 peserta, MOP 1.038 peserta, Kondom 19.138 peserta, Suntik I I 4.643 peserta, dan Pil I03.05 (BKKBN Batam, 2015).

Menurut BKKBN (Badan Kependudukan dan Keluarga Berencana Nasional) di Kota Batam pada bulan Desember tahun 2015 mencatat jumlah peserta KB aktif yaitu 174.417 jenis kontrasepsi yang digunakan yaitu IUD 15.966 peserta, MOW 4.579 peserta, Implant II.903 peserta, MOP 919 peserta, Kondom 14.769 peserta, Suntik 67.638 peserta, dan Pil 58.643 peserta. Berdasarkan BKKBN kota Batam tahun 2015 menunjukkan angka peserta $K B$ yang tertinggi yaitu $K B$ suntik sebanyak 67.638 peserta (BKKBN Batam, 2015). Efek samping konrasepsi suntik yang paling tinggi frekuensinya yaitu peningkatan berat badan. Penyebab pertambahan berat badan tidak jelas. Hipotesa para ahli, DMPA (Depo Medroksi Progesterone Asetate) merangsang pusat pengendali nafsu makan $\mathrm{di}$ hypothalamus, yang menyebabkan akseptor makan lebih daripada biasanya. Untuk menndapatkan gambaran nyata tentang kejadian peningkatan berat badan yang dialami akseptor kontasepsi suntik maka perlu dilakukan suatu penelitian untuk mengetahui sejauh mana pengaruh kontrasepsi suntik dengan perubahan berat badan (Hartanto, 2004). 
Pada tahun 2013 telah dilakukan penelitian oleh Adriana Palimbo dkk dengan judul “Hubungan Lama Penggunaan Kontrasepsi Suntik 3 Bulan dengan Kenaikan Berat Badan Pada Wanita Akseptor KB di Wilayah Kerja Puskesmas Lok Baintan”. Penelitian ini menggunakan metode survey analitik dengan pendekatan cross sectional study. Terdapat 73 sampel dengan menggunakan accidental sampling artinya setiap ibu yang datang ke puskesmas Lok Baintan untuk melakukan suntik KB 3 bulan dijadikan sampel. Instrument penelitian berupa lembar observasi yang di analisis menggunakan Uji Statistik Chi Square. Hasil penelitian penggunaan lebih dari I tahun ( > I tahun) sebanyak 73\% pada akseptor KB Suntik 3 bulan, 55,8\% mengalami kenaikan berat badan pada wanita akseptor KB suntik 3 bulan dan terdapat hubungan yang signifikan antara penggunaan KB suntik 3 bulan dengan kenaikan berat badan $(p=0,002<\alpha=0,05)$.

Berdasarkan fenomena-fenomena diatas, maka penulis tertarik melakukan penelitian mengenai "Hubungan Pengetahuan dan Lama Pemakaian KB Suntik 3 Bulan dengan Perubahan Berat Badan pada Akseptor KB di Bidan Praktik Swasta Veronica Nongsa Batu Besar Kota Batam.

\section{METODOLOGI}

Metode kegiatan penelitian ini dilakukan menggunakan metode penelitian deskriptif analitik yaitu peneliti hanya akan mendeskripsikan variabel tertentu dengan metode penelitian kuantitatif yang bersifat analitik dengan rancangan penelitian cross sectional. Penelitian ini dilakukan di Bidan Praktik Swasta Veronica Nongsa Batu Besar Kota Batam dilaksanakan pada tanggal 23 Maret 15 April 2016, dengan populasi dalam penelitian ini adalah seluruh Akseptor KB suntik 3 bulan di Bidan Praktik Swasta Veronica Nongsa Batu Besar Kota Batam dan pengambilan sampel pada penelitian ini dengan total sampling yaitu sebanyak 60 orang. Instrument dalam penelitian ini menggunakan data primer menggunakan lembar kuesioner untuk mengumpulkan data secara langsung.

Teknik pengumpulan data dalam penelitian ini dimulai dari permohonan ijin lahan kemudian mulai menentukan jumlah populasi dan sampel dan selanjutnya peneliti menentukan responden yang memenuhi kriteria Inklusi dan peneliti menyebarkan lembar Informed Consent terlebih dahulu kepada responden, setelah disetujui oleh responden maka dilanjutkan untuk melakukan pengisian kuesioner, Setelah peneliti mengumpulkan data primer segera peneliti melakukan pengolahan data dengan cara editing, koding, rekapitulasi data, entry data kemudian dikelola dengan statistika analitik dengan metode analisis data seperti analisis univariat dan bivariat. Setelah dilakukan analisis data, peneliti menyajikan dalam bentuk paparan hasil, tabel dan diagram dengan di simpulkan semua hasil akhir yang didapatkan.

\section{HASIL DAN PEMBAHASAN}

\section{Hasil Penelitian}

Hasil penelitian tentang Hubungan Pengetahuan dan Lama Pemakaian KB Suntik 3 Bulan dengan Perubahan Berat Badan pada Akseptor KB di Bidan Praktek Swasta Veronica Nongsa Batu Besar Kota Batam yang dilakukan pada 23 Maret-I5 April 2016.

\section{Analisa Univariat}

Distribusi Frekuensi berdasarkan Pengetahuan Akseptor KB Suntik 3 Bulan di BPS Veronica Nongsa Batu Besar Tahun 2016.

Distribusi Frekuensi Pengetahuan Akseptor KB Suntik 3 Bulan di BPS Veronica Nongsa Batu Besar Kota Batam Tahun 2016.

\begin{tabular}{ccc}
\hline Pengetahuan & Frekuensi (f) & Persentasi (\%) \\
\hline Kurang & 20 & 33,3 \\
Cukup & 10 & 16,7 \\
Baik & 30 & 50,0 \\
\hline Jumlah & 60 & 100 \\
\hline
\end{tabular}

Berdasarkan Tabel diatas menunjukkan bahwa dari 60 responden Akseptor KB Suntik 3 Bulan di BPS Veronica 
Nongsa Batu Besar Kota Batam, responden yang memiliki pengetahuan baik 30 responden (50,0\%), responden yang memiliki pengetahuan kurang 20 responden $(33,3 \%)$ dan yang memiliki pengetahuan cukup 10 responden $(16,7 \%)$.

Distribusi Frekuensi Lama Pemakaian KB Suntik 3 Bulan di BPS Veronica Nongsa Batu Besar Kota Batam Tahun 2016.

Distribusi Frekuensi Lama Pemakaian KB Suntik 3 Bulan di BPS Veronica Nongsa Batu Besar Kota Batam Tahun 2016.

\begin{tabular}{ccc}
\hline Lama Pemakaian & Frekuensi $(f)$ & Persentasi (\%) \\
\hline$<$ I tahun & 16 & 26,7 \\
$>$ I tahun & 44 & 73,3 \\
& & \\
\hline Jumlah & 60 & 100 \\
\hline
\end{tabular}

Berdasarkan Tabel diatas menunjukkan bahwa dari 60 responden Akseptor KB Suntik 3 bulan di BPS Veronica Nongsa Batu Besar Kota Batam, lebih banyak responden yang lama pemakaiannya $>I$ tahun menggunakan KB Suntik 3 bulan sebanyak 44 (73\%) dibandingkan dengan responden yang lama pemakaiannya < I tahun menggunakan KB Suntik 3 Bulan sebanyak 16 (27\%).

Distribusi Frekuensi Perubahan Berat Badan pada Akseptor KB Suntik 3 Bulan di BPS Veronica Nongsa Batu Besar Kota Batam Tahun 2016.

Distribusi Frekuensi Perubahan Berat Badan pada Akseptor KB Suntik 3 Bulan di BPS Veronica Nongsa Batu Besar Kota Batam Tahun 2016.

\begin{tabular}{ccc}
\hline Perubahan Berat Badan & Frekuensi (f) & Persentase (\%) \\
\hline Menurun & 4 & 6,7 \\
Meningkat & 56 & 93,3 \\
\hline Jumlah & 60 & 100 \\
\hline
\end{tabular}

Berdasarkan Tabel diatas menunjukkan bawah dari 60 responden Akseptor KB Suntik 3 Bulan di BPS Veronica Nongsa Batu Besar Kota Batam, lebih banyak mengalami peningkatan berat badan yaitu 56 (93\%) responden dibandingkan responden mengalami penurunan berat badan yaitu 4 (7\%) responden.

\section{Analisa Bivariat}

Analisa bivariat bertujuan untuk mengetahui hubungan antara pengetahuan dan lama pemakaian KB Suntik 3 bulan dengan perubahan berat badan pada akseptor KB di Bidan Praktik Swasta Veronica Nongsa Batu Besar Kota Batam.

a. Hubungan Pengetahuan KB Suntik 3 Bulan dengan Perubahan Berat Badan pada Akseptor KB di BPS Veronica Nongsa Batu Besar Kota Batam Tahun 2016.

Hubungan Pengetahuan KB Suntik 3 Bulan dengan Perubahan Berat Badan pada Akseptor KB di BPS Veronica Nongsa Batu Besar Kota Batam Tahun 2016.

\begin{tabular}{|c|c|c|c|c|c|c|c|}
\hline \multirow{3}{*}{$\begin{array}{c}\text { Pengetahuan } \\
\text { Kurang }\end{array}$} & \multicolumn{4}{|c|}{ Perubahan Berat Badan } & \multirow{3}{*}{$\begin{array}{c}\text { Total } \\
20\end{array}$} & \multirow{3}{*}{$\%$} & \multirow{3}{*}{$\begin{array}{l}\text { P- } \\
\text { Val } \\
\text { ue }\end{array}$} \\
\hline & \multicolumn{2}{|c|}{ Menurun } & \multicolumn{2}{|c|}{ Meningkat } & & & \\
\hline & 2 & $3,3 \%$ & 18 & $30 \%$ & & & \\
\hline Cukup & 0 & $0,0 \%$ & 10 & $16,7 \%$ & 10 & 10 & 0,5 \\
\hline Baik & 2 & $3,3 \%$ & 28 & $46,7 \%$ & 30 & 0 & 85 \\
\hline Jumlah & 4 & $6,6 \%$ & 56 & $93,4 \%$ & 60 & & \\
\hline
\end{tabular}

Berdasarkan Tabel diatas diketahui bahwa dari 60 responden Akseptor KB Suntik 3 Bulan di BPS Veronica Nongsa Batu Besar Kota Batam, lebih banyak responden memiliki pengetahuan baik dengan perubahan berat badan meningkat sebanyak 28 (46,7\%) dan dengan perubahan berat badan menurun sebanyak $2(3,3 \%)$, pada responden yang memiliki pengetahuan kurang mengalami perubahan berat badan meningkat sebanyak $18(30,0 \%)$ responden dan dengan perubahan berat badan menurun sebanyak 2 (3,3\%) dan pengetahuan cukup yang mengalami perubahan berat badan meningkat sebanyak 10 (16,7\%) responden.

Dari hasil perhitungan Chi-Square didapatkan nilai $p$-value sebesar 0,585 karena hasil $p$-value 0,585 > 0,05, maka $\mathrm{H}_{\mathrm{a}}$ ditolak, maka dapat disimpulkan bahwa tidak ada hubungan yang signifikan antara pengetahuan akseptor KB suntik 3 bulan dengan perubahan berat badan di BPS Veronica Nongsa Batu Besar Kota Batam Tahun 2016.

b. Hubungan Lama Pemakaian KB Suntik 3 Bulan dengan Perubahan Berat Badan pada Akseptor KB di BPS Veronica Nongsa Batu Besar Kota Batam Tahun 2016. 
Hubungan Lama Pemakaian KB Suntik 3 Bulan dengan Perubahan Berat Badan pada Akseptor KB di BPS Veronica Nongsa Batu Besar Kota Batam Tahun 2016.

\begin{tabular}{cccccccc}
\hline Lama & \multicolumn{2}{c}{ Perubahan Berat Badan } & Total & $\%$ & p-value \\
\cline { 2 - 5 } Pemakaian & \multicolumn{2}{l}{ Menurun } & \multicolumn{2}{c}{ Meningkat } & & & \\
\hline$<$ I tahun & 3 & $5,0 \%$ & 13 & $21,7 \%$ & 16 & 100 & 0,054 \\
$>$ Itahun & 1 & $1,7 \%$ & 43 & $71,7 \%$ & 44 & & \\
\hline Jumlah & 4 & $6,7 \%$ & 56 & $93,4 \%$ & 60 & & \\
\hline
\end{tabular}

Berdasarkan Tabel diatas diketahui bahwa dari 60 responden Akseptor KB Suntik 3 Bulan di BPS Veronica Nongsa Batu Besar Kota Batam, akseptor yang lama pemakaiaan KB suntik 3 bulan > I tahun (Lama) yang mengalami perubahan berat badan yang meningkat sebanyak $43(71,7 \%)$ responden dan yang mengalami perubahan berat badan yang menurun sebanyak 3 $(5,0 \%)$ responden.

Akseptor yang lama pemakaiaan KB suntik 3 bulan < I tahun (Baru) yang mengalami perubahan berat badan yang meningkat sebanyak $13(21,7 \%)$ responden dan yang mengalami perubahan berat badan yang menurun sebanyak I (I,7\%) responden.

Dari hasil perhitungan Chi-Square didapatkan nilai $p$-value sebesar 0,054 karena hasil p-value 0,054 > 0,05, maka $\mathrm{H}_{\mathrm{a}}$ ditolak, maka dapat disimpulkan bahwa tidak ada hubungan yang signifikan antara lama pemakaian KB Suntik 3 bulan dengan perubahan berat badan pada akseptor KB di BPS Veronica Nongsa Batu Besar Kota Batam tahun 2016.

\section{Pembahasan Penelitian}

\section{Univariat}

\section{a. Pengetahuan KB Suntik 3 Bulan pada Akseptor KB}

Berdasarkan hasil penelitian menunjukkan bahwa dari 60 responden KB Suntik 3 bulan di BPS Veronica Nongsa Batu Besar Kota Batam, lebih banyak memiliki pengetahuan baik sebanyak 30 responden (50,0\%), pengetahuan cukup sebanyak 10 responden (16,7\%) dan pengetahuan kurang sebanyak 20 responden (33,3\%).

Berdasarkan hasil penelitian ini menunjukkan bahwa lebih banyak responden akseptor KB suntik 3 bulan berpendidikan SMA sebanyak 38 responden (63\%),
Perguruan Tinggi sebanyak 15 responden (25\%) dan SMP sebanyak 7 responden (12\%). Dapat disimpulkan dari analisa tersebut bahwa tingginya pendidikan responden yang dimiliki sangat membantu dalam tingginya pengetahuan akseptor KB suntik 3 bulan. Hal ini sesuai dengan teori yang dikemukakan oleh Notoadmojo (2010) semakin tinggi pendidikan seseorang, maka semakin baik pula pengetahuan yang akan dimiliki.

\section{b. Lama Pemakaian KB Suntik 3 Bulan}

Berdasarkan hasil penelitian menunjukkan bahwa dari 60 responden akseptor $K B$ suntik 3 bulan di BPS Veronica Nongsa Batu Besar Kota Batam, lebih banyak akseptor yang lama pemakaiaan KB Suntik 3 bulan > I tahun sebanyak 44 responden (73,3\%) dibandingkan dengan akseptor yang lama pemakaian KB suntik 3 bulan < I tahun yaitu sebanyak 16 responden $(26,7 \%)$,

Berdasarkan hasil penelitian ini didapatkan responden yang lebih banyak menggunakan KB suntik 3 bulan dengan jangka waktu lama dikarenakan sebagian responden cocok dengan KB tersebut. Disamping itu, selain responden cocok menggunakan $\mathrm{KB}$ tersebut responden lebih nyaman karena KB suntik 3 bulan tidak mendapatkan haid. $\mathrm{Hal}$ ini sejalan dengan penelitian yang dilakukan oleh Diana Purnama Sari (2009), bahwa berdasarkan lama pemakaian KB suntik DMPA dari 30 responden terdapat 7 responden $(23,34 \%)$ yang memakai KB suntik DMPA selama I-3 tahun, 8 responden (26,06\%) yang memakai $K B$ suntik DMPA selama 3-4 tahun dan 15 responden (50\%) yang memakai KB suntik DMPA selama 4 tahun.

c. Perubahan Berat Badan pada Akseptor KB Suntik 3 Bulan

Berdasarkan hasil penelitian menunjukkan bahwa dari 60 responden akseptor KB suntik 3 bulan di BPS Veronica Nongsa Batu Besar Kota Batam, lebih banyak responden yang mengalami perubahan berat badan yang meningkat sebanyak 52 
responden $(93,3 \%)$ sedangkan pada responden yang mengalami perubahan berat badan yang menurun sebanyak 4 responden (6,7\%).

Hal ini sejalan dengan penelitian yang dilakukan oleh Diana Purnama Sari (2009) bahwa hasil penelitian adanya berat badan yang tetap dan berat badan yang turun yaitu ada 4 responden (13,34\%) yang berat badannya tetap dan ada 4 responden (13,34\%) yang berat badannya turun tetapi jumlahnya relative lebih kecil dari responden yang mengalami kenaikan berat badan. Akseptor KB suntik DMPA yang mengalami peningkatan berat badan tidak hanya disebabkan karena kandungan hormone progesterone dalam DMPA tetapi ada faktor-faktor lain yang mempengaruhi.

\section{Bivariat}

a. Hubungan Pengetahuan KB Suntik 3 Bulan dengan Perubahan Berat Badan pada Akseptor KB

Berdasarkan hasil penelitian menunjukkan bahwa dari 60 responden akseptor KB suntik 3 bulan di BPS Veronica Nongsa Batu Besar Kota Batam, sebagian besar memiliki pengetahuan baik dengan perubahan berat badan yang meningkat sebanyak 28 responden (46,7\%). Dengan hasil perhitungan Chi-Square didapatkan p-value sebesar 0,585 >0,05 maka $\mathrm{H}_{\mathrm{a}}$ ditolak, maka dapat disimpulkan bahwa tidak ada hubungan yang signifikan antara pengetahuan akseptor dengan perubahan berat badan di BPS Veronica Nongsa Batu Besar Kota Batam Tahun 2016.

b. Hubungan Lama Pemakaian KB Suntik 3 Bulan dengan Perubahan Berat Badan

Berdasarkan hasil penelitian yang menunjukkan bahwa dari 60 responden akseptor KB Suntik 3 Bulan di BPS Veronica Nongsa Batu Besar Kota Batam, lebih banyak akseptor yang lama pemakaiannya > I tahun mengalami perubahan berat badan yang meningkat yaitu sebanyak 43 responden (7I,7\%). Dengan hasil perhitungan Chi-Square didapatkan p-value sebesar 0,054 > 0,05 maka $\mathrm{H}_{\mathrm{a}}$ ditolak, maka dapat disimpulkan bahwa tidak ada hubungan yang signifikan antara lama pemakaian dengan perubahan berat badan di BPS Veronica Nongsa Batu Besar Kota Batam Tahun 2016.

\section{KESIMPULAN}

Berdasarkan hasil penelitian dan pengolahan data yang telah dilaksanakan oleh peneliti mengenai Hubungan Pengetahuan dan Lama Pemakaian KB Suntik 3 Bulan dengan Perubahan Berat Badan pada Akseptor KB di BPS Veronica Nongsa Batu Besar Kota Batam Tahun 2016 dengan jumlah responden 60 dapat disimpulkan bahwa :

a. Hasil penelitian menunjukkan bahwa dari 60 responden akseptor KB suntik 3 bulan di BPS Veronica Nongsa Batu Besar Kota Batam Tahun 2016 sebagian besar mempunyai pengetahuan yang baik yaitu sebanyak 30 responden (50,0\%).

b. Hasil penelitian menunjukkan bahwa dari 60 responden, akseptor yang lama pemakaian KB suntik 3 bulan yaitu > I tahun sebanyak 44 responden $(73,3 \%)$.

c. Hasil penelitian menunjukkan bahwa dari 60 responden akseptor KB Suntik 3 bulan di BPS Veronica Nongsa Batu Besar Kota Batam Tahun 2016 sebagian besar akseptor mengalami perubahan berat badan yang meningkat yaitu sebanyak 56 responden $(43,3 \%)$.

d. Dari hasil penelitian yang telah dilakukan, tidak adanya Hubungan Pengetahuan dan Lama Pemakaian KB Suntik 3 Bulan dengan Perubahan Berat Badan di BPS Veronica Nongsa Batu Besar Kota Batam Tahun 2016.

\section{UCAPAN TERIMA KASIH}

Tim penulis mengucapkan terima kasih kepada semua pihak yang telah membantu kelancaran pelaksanaan 
Penelitian ini di BPS Veronica Nongsa Batu Besar Kota

Batam, dan segenap civitas akademika STIKes Awal Bros

Batam dan Yayasan Bangun Bangsa.

\section{REFERENSI}

I. Ariani P.A. (20|4). Aplikasi Metodologi Penelitian Kebidanan dan Kesehatan Reproduksi. Nuha Medika. Yogyakarta

2. BKKBN. (200I). Informasi Pelayanan Kontrasepsi. DepKes RI. Jakarta

3. BKKBN. (20I5). Peserta KB AktifKepulauan Riau dan Batam.

4. Handayani, S. (2010). Buku Ajar Pelayanan Keluarga Berencana. Yogyakarta: Pustaka Rihana

5. Notoatmodjo, S. (2010). Metodologi Penelitian Kesehatan. Jakarta: Rineka Cipta

6. Nurjanah, (2006). Perbandingan Perubahan Berat Badan Pada Penggunaan Kontrasepsi Suntik DMPA dan Pil Kombinasi Pada Akseptor KB di Puskesmas Tegalrejo. Yogyakarta. Keperawatan. Yogyakarta.

7. Suparyanto, (2010). Pengaruh KB Suntik Terhadap Perubahan Berat Badan. Http:www.drsuparyanto.blogspot.co.id, terbit 12 desember 2010 diperoleh 29 Februari 2016 20:30 WIB

8. Wijayanti, (2006). Perbedaan Peningkatan Berat Badan Antara Akseptor Keluarga Berencana Suntik Progesterone Tunggal dan Kombinasi Progesterone Esterogene di Klinik Kebidanan dan Reproduksi Bahagia Surakarta. UNS. Surakarta

9. Yeni, (20|3). Faktor-faktor Yang Mempengaruhi Pemilihan Alat Kontrasepsi Suntik di Puskesmas Botania Kota Batam. Karya Tulis IImiah, STIKes Awal Bros Batam. 